\title{
PUBLIC SECTOR WAGE GROWTH IN ALBERTA
}

\author{
Ken Boessenkool and Ben Eisen
}

\section{SUMMARY}

In recent years, Alberta's fiscal stance has shifted from large surpluses to deficits, and a large part of the blame appears to be due to rising public sector salaries. Since 2000 , the province's public sector wage bill has shot up by 119 percent - almost double the rate of growth in the rest of Canada. Wages, previously roughly at par with the rest of the country, are now higher (in many cases very substantially) across all public sector categories, including health care, social services, education and government, consuming 95 percent of the increase in provincial revenues over the past decade. At the same time, the number of public sector employees has grown faster than the overall population; it is difficult to attribute this sharp uptick to a rise in productivity, or the need to compete with private industry for skilled workers. This paper breaks down the increases in every category, arguing that if the provincial government is looking to trim expenditures, public sector salaries are a good place to start. The authors make their case using detailed Statistics Canada data, throwing down the gauntlet to defenders of the status quo and challenging them to justify these disparate increases. 


\section{INTRODUCTION}

In the last decade of the 20th century Alberta became a paragon of fiscal virtue. Following an election in 1993 fought over how deeply Alberta needed to cut spending, the provincial government set the standard for having a transparent and closely controlled fiscal framework and also vigorously reduced its expenditures. And it reaped the rewards of that fiscal virtue by paying down debt and making productivity-enhancing tax cuts, including the move to a single rate of personal income tax.

In the first decade of the 21st century Alberta's fiscal stance shifted from large surpluses to deficits. This return to deficits has raised the question of how the province addresses its deficit. If Alberta has a spending problem, it makes sense to focus on expenditure reductions to reduce the deficit. If not, then relying on economic growth or tax increases might be the appropriate response.

Boessenkool undertook a comparative examination of spending by the government of the province of Alberta. ${ }^{l}$ He showed that in per-capita terms, the provincial government in Alberta delivers services to its population by spending 40 percent more than the provincial government in Ontario, 30 percent more than British Columbia and 15 percent more than the average in the other nine provinces. In dollar terms, program spending in Alberta would have to be reduced by $\$ 5$ billion to bring its per-person spending in line with the other nine provinces. Cuts of $\$ 12$ and $\$ 8$ billion would be required to bring Alberta's provincial government spending in line with Ontario and British Columbia, respectively. One of the largest expenditures the provincial government makes is for public sector wages and salaries - both for its own employees and the employees of the medical, education and social service sectors.

Laurin and Robson identified growth in the public sector wage bill as a contributor to the problem of government deficits in Canada, and specifically recommended that the federal government should curb spending on government salaries as a strategy for returning to fiscal balance as quickly as possible. ${ }^{2}$ Laurin and Robson observe that, at the federal level, the total cost of wages and salaries for non-military/RCMP personnel increased by more than 90 percent during the decade between fiscal years 1999/2000 and 2009/2010, and that this has helped fuel higher spending and deficits. ${ }^{3}$ Comparable growth in the government wage bill at the provincial level would likely place even greater strain on these governments' budgets, since public employee compensation costs consume a much larger share of expenditures for sub-national governments.

To preview our conclusions, in the year 2000, per-employee spending on public sector wages and salaries at the local and provincial levels in Alberta was approximately in line with the national average. Over the past decade, per-employee compensation costs have increased across Canada, but have grown dramatically faster in Alberta.

\footnotetext{
1 Boessenkool, Ken, February 2010. Does Alberta Have a Spending Problem? Calgary, The School of Public Policy.

2 Laurin, Alexandre and William B.P. Robson, February 2011. A Faster Track to Fiscal Balance: The 2011 Shadow Budget Toronto: CD Howe Institute.

3 Op. cit.
} 
Currently, per-employee compensation costs for Alberta's general government employees are 35 percent higher than per-employee compensation costs for this category in the rest of Canada. For health and social services employees, government spending on wages and salaries per employee is 60 percent higher in Alberta than in the rest of Canada. For local school board employees, the gap is somewhat lower at 10 percent. Per-employee compensation costs for Alberta's public employees in the post-secondary education sector are 30 percent higher than per-employee compensation costs for this category of employee in the rest of Canada.

\section{GROWTH IN ALBERTA'S TOTAL PUBLIC SECTOR WAGE BILL}

For provincial and local governments across Canada, the government wage bill (the wages and salaries paid to public employees) is the single largest expenditure. In 2000, for example, the total wage bill was just over one-quarter of total expenditures. This section of the paper examines public sector wage-bill growth over the past decade.

Using Statistics Canada data, it is relatively straightforward to measure the impact of rising wage-bill costs on the fiscal position of the provincial and local governments in Alberta. CANSIM Table 183-0002 provides statistics on total government spending on wages and salaries for public employees at the federal, provincial and local levels. This table divides up the sub-federal public sector (excluding crown corporations) into five categories: provincial general government, health and social service institutions, colleges and universities, local school boards and local general government. This paper focuses on the first four, all of which are funded by the provincial government.

Sub-federal spending on public employee wages and salaries has grown far faster in Alberta than in the country taken as a whole. In the year 2000, the combined cost of the total wages and salaries for public sector employees in these four categories was approximately $\$ 6.8$ billion. By the year 2010, the wage and salary bill for these categories of public employees reached $\$ 14.9$ billion - an increase of 119 percent in a decade. By comparison, in the rest of Canada (ROC), the total wage bill for these four categories of employees increased by 63 percent, just over half as large an increase as occurred in Alberta.

These numbers are of particular interest when compared with total revenue growth for Alberta over the past 10 years. In 2000-01 total provincial revenues were $\$ 25.5$ billion. In 2010-11 revenues grew to $\$ 34.0$ billion, an $\$ 8.5$ billion dollar increase. If we look at the four categories of public sector wages noted above, we see an increase in wages of $\$ 8.1$ billion. In other words, 95 percent of the increase in provincial revenues over the last decade has gone directly into the pockets of public sector employees. The total wage bill rose to nearly 45 percent of total expenditure in 2010 from just over a quarter in 2000. 
TABLE 1: Total Wage Bill Comparisons for 1990s and 2000s in nominal dollars (millions)

\begin{tabular}{|l|r|r|}
\hline & Alberta & Rest of Canada \\
\hline Wage Bill in 1990 & $5,515.338$ & $51,401.771$ \\
Wage Bill in 2000 & $6,776.909$ & $65,007.748$ \\
Growth over Decade & $22.87 \%$ & $26.47 \%$ \\
\hline Wage Bill in 2000 & & \\
Wage Bill in 2010 & $6,776.909$ & $65,007.748$ \\
Growth over Decade & $14,873.226$ & $105,989.237$ \\
\hline
\end{tabular}

It is reasonable to ask whether the jump in public sector wages in the decade since the turn of the century was a needed correction for an overly harsh reduction of wages during the fiscal retraction of the 1990s. Table 1 shows that is not the case. Public sector wages did rise slower in Alberta during the 1990s than in the rest of the country, but by nowhere near the amount by which they grew faster during the more recent decade. Wages in Alberta, and in the rest of Canada (ROC) grew more modestly in the 1990s as all governments implemented fiscal retrenchment to address deficits. But the gap in favour of the rest of Canada of under four percentage points during the 1990s pales in comparison to the gap in favour of Alberta of well over 50 percentage points in the decade after the turn of the century.

Looking at the total wage bill has two problems. First, there exist some composition differences across provinces. For example, Ontario has decentralized some of its social service spending to municipalities, so those employees would show up as part of local government in Ontario and provincial government elsewhere. To the extent the wage paid to those employees differ from the average, this shuffling between government sectors might have a small influence on wage bill comparisons across provinces. Second, looking at the total wage bill does not allow us to identify how much of its growth may have been due to growth in provincial population requiring additional public sector employees.

We can minimize the impact of these issues by comparing per-employee spending on public sector wages across our four categories of spending. This is what we do below.

\section{PER-EMPLOYEE SPENDING ON PUBLIC SECTOR WAGES IN ALBERTA VS. OTHER PROVINCES}

Statistics Canada tracks public sector employment data for each province, including the total number of public sector employees and the total amount of money spent by governments on their wages and salaries. All public sector employees in each province are divided up into seven different categories: federal general government, provincial general government, local general government, health and social service institutions, universities and colleges, local school boards and government business enterprises. In this analysis, we will focus on the categories of employees whose wage and salary levels have the greatest impact on provincial government finances - provincial general government, health and social institutions, universities and colleges and local school boards. 
Chart 1 shows that in the year 2000, Alberta's total spending on wages and salaries per employee was close to the Canadian average in each of these four categories. For three categories (local school boards, health and social service institutions and provincial general government), Alberta's per-employee wages were slightly below the national average, and in one category, per-employee compensation in Alberta was slightly above the national average.

CHART 1: Wages and Salaries Per Employee, Alberta and Rest of Canada (ROC), Nominal Dollars 2000

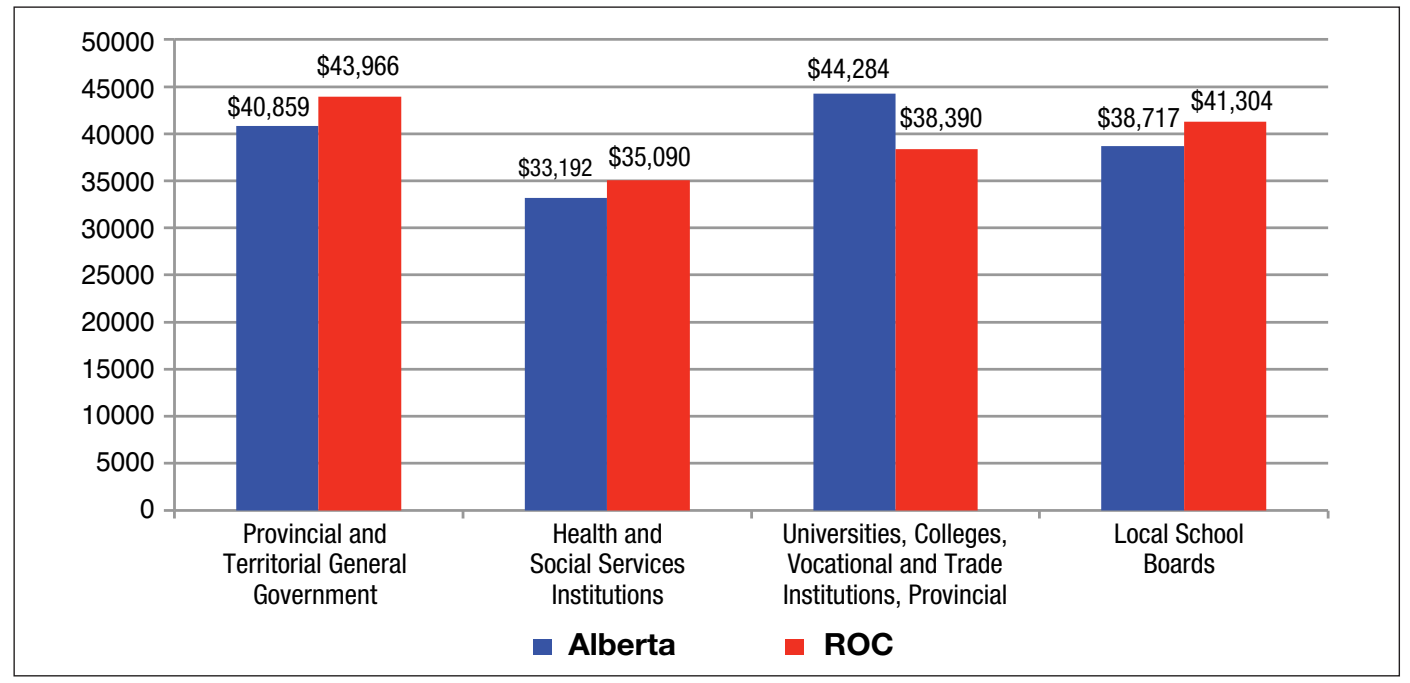

Over the next decade, (see Chart 2) spending on wages per employee increased significantly more rapidly in Alberta than in rest of Canada for each of these four categories. The following paragraphs and Charts 3 through 7 show that as a result of this uniquely rapid wage growth, by 2010, per-employee spending on wages in Alberta was either the highest or next-to-highest in Canada in each of these categories.

We now turn to a breakdown of the data in Chart 2 by category and by province.

CHART 2: Wages and Salaries Per Employee, Alberta and Rest of Canada (ROC), Nominal Dollars 2010

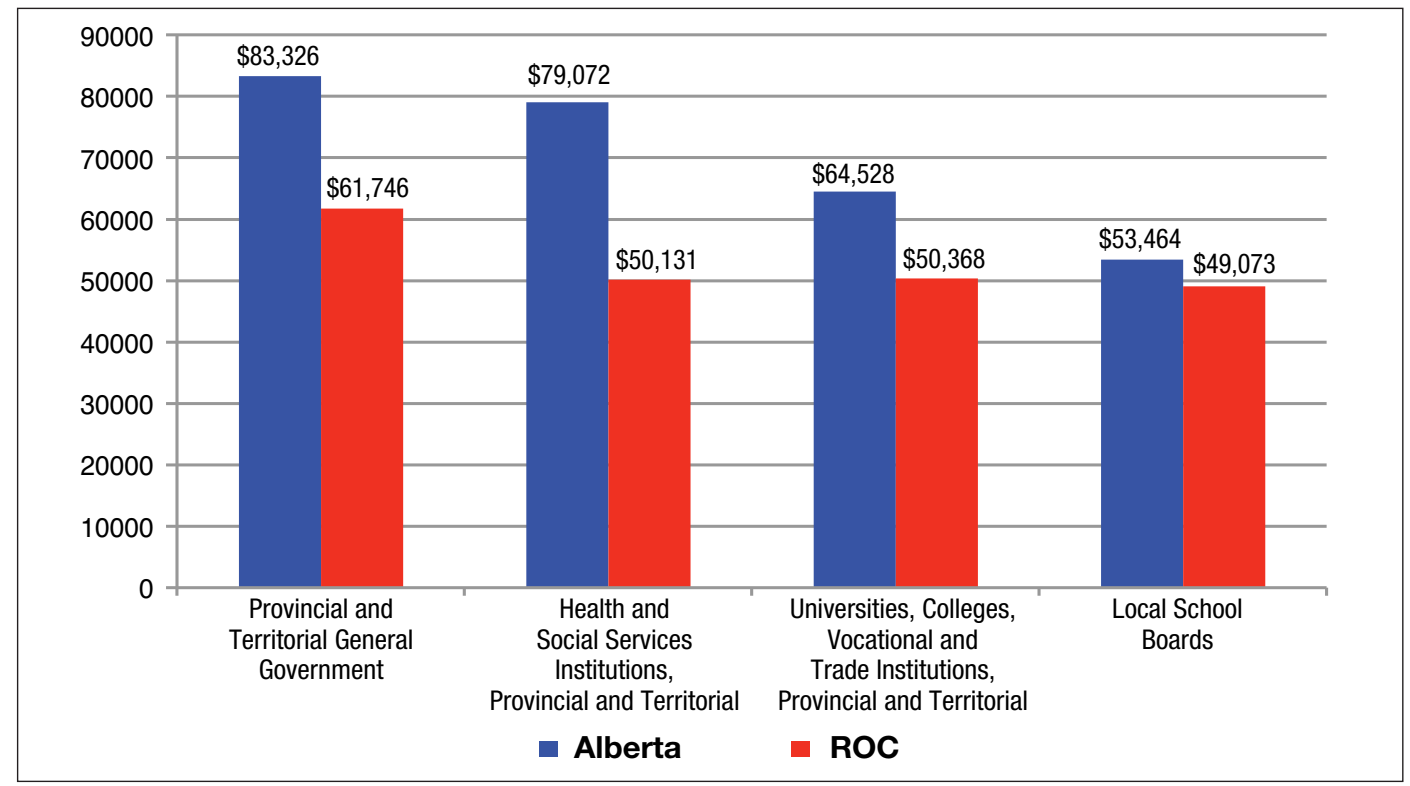




\section{Provincial General Government}

The provincial general government category of public sector employees includes 29,456 civil servants directly employed by the government of Alberta in 2010. In the year 2000, Alberta's per-employee spending on wages and salaries for this category of government workers was below the average in the rest of Canada (Chart 1). Over the next 10 years, total spending peremployee on wages and salaries for workers in this category increased by 103 percent in Alberta, compared to an increase of 40 percent in the rest of Canada. As a result, in 2010 Alberta had the highest level of spending on wages and salaries per employee in Canada for provincial general government workers (Chart 3). In 2010, per-employee wage costs for this category were 35 percent higher in Alberta than in the rest of Canada, and were 15 percent higher in Alberta than Saskatchewan, the province with the next highest level of wage costs per employee.

CHART 3: Spending on Wages and Salaries Per Employee: Provincial General Government (2010)

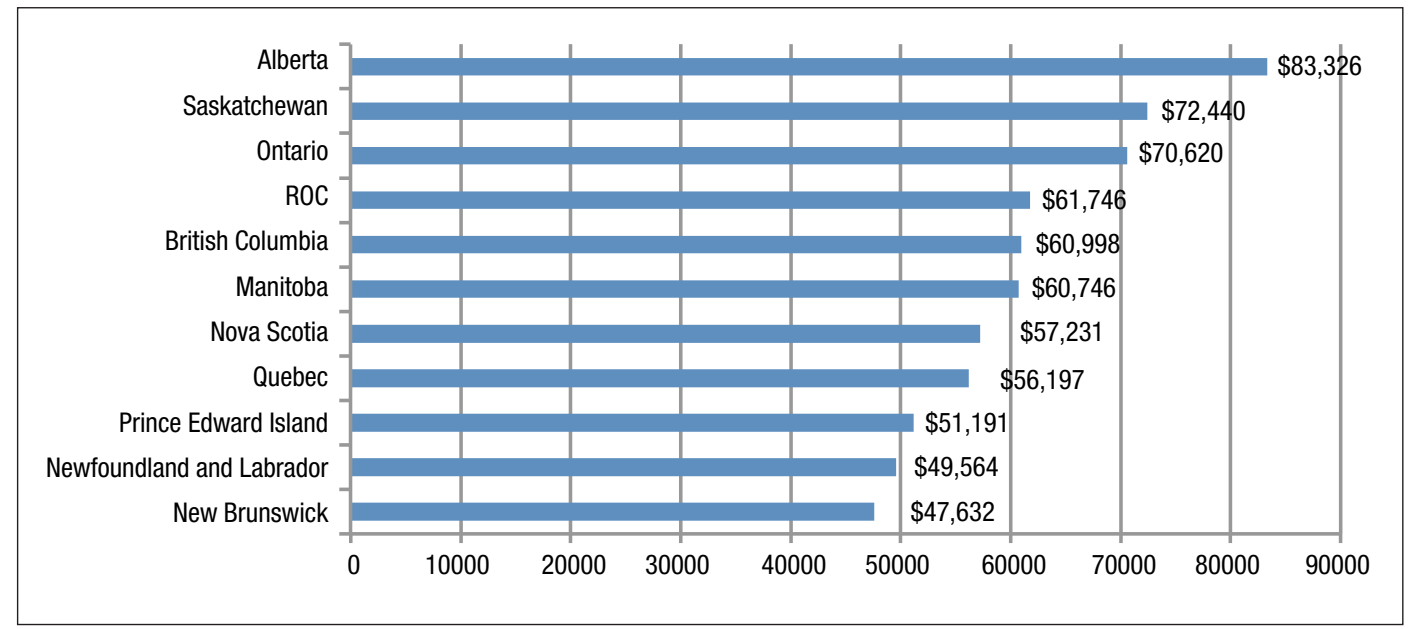

\section{Health And Social Services Institutions}

In the year 2000, Alberta's per-employee spending on wages and salaries for public sector workers employed within health and social services institutions was below the average for the rest of Canada (Chart 1). Over the next decade, the growth of spending on wages per employee in Alberta increased much faster than in the rest of Canada, reaching \$79,072 in 2010 (see Chart 4). During this period, per-employee spending on wages and salaries in this category increased by 138 percent in Alberta, compared to a 43 percent increase in the rest of Canada. As a result, Alberta's per-employee public sector wage bill within public health and social services institutions is currently, by far, the largest in the country. In Alberta, per-employee wage spending in this category was 58 percent higher than the rest of the country in 2010. Wage spending per employee was 37 percent higher in Alberta than in Ontario, the province with the next highest level of per-employee spending on wages and salaries. This is the largest single category of government workers, with 72,581 employees included in this category for Alberta in 2010. 
CHART 4: Spending on Wages and Salaries Per Employee: Health and Social Services Institutions (2010)

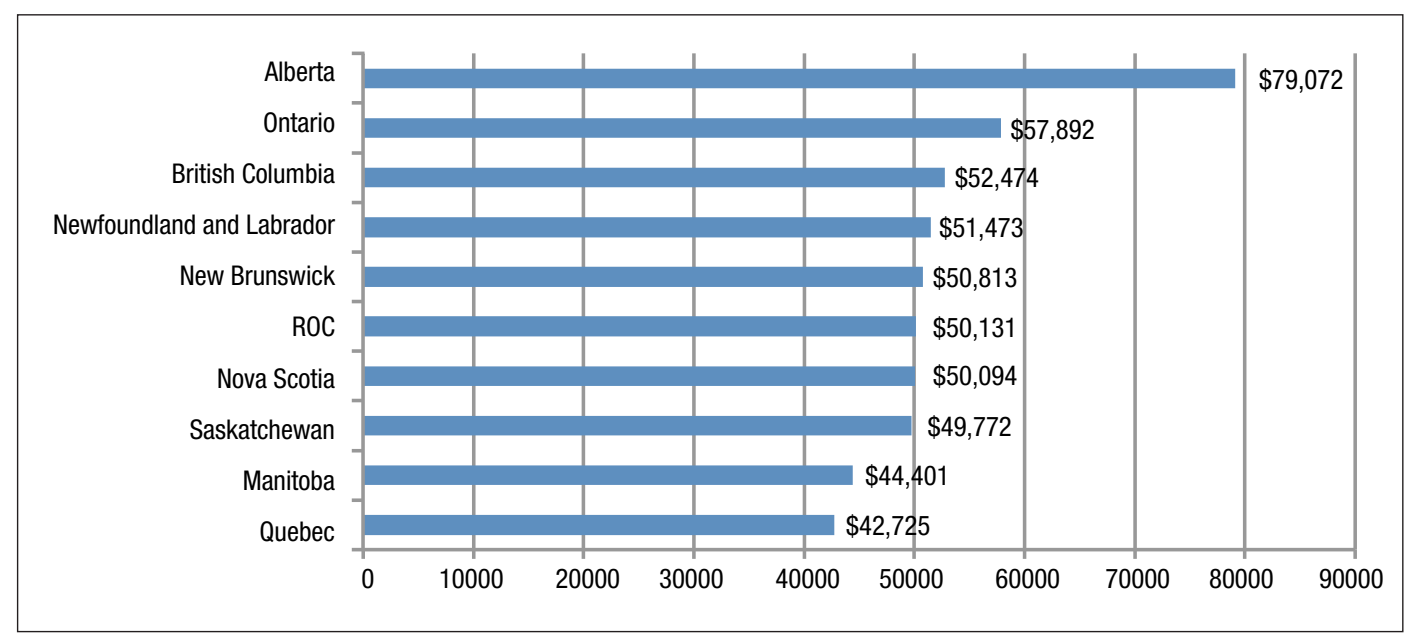

\section{Local School Boards}

Alberta's spending on the wages and salaries of employees at local school boards shows a similar pattern, although increases in spending on wages per employee in this category have generally been smaller than in the two categories that have already been discussed, both in Alberta and in the rest of Canada. As reported in Chart 2, in 2000, per-employee spending on wages and salaries in this category was lower in Alberta than in the rest of Canada. Between 2000 and 2010, per-employee wage costs in this category increased by 38 percent in Alberta, twice the 19 percent increase that occurred in the rest of the country. As a result, Alberta's peremployee spending on wages was slightly higher than in the rest of Canada within local school boards in 2010 .

As Chart 5 shows, per-employee wage spending in Alberta in 2010 for this category was nine percent above the average in the rest of Canada. Alberta had the second highest level of peremployee spending on wages and salaries in local school boards, behind only Ontario, where per-employee wage spending was six percent higher than in Alberta.

CHART 5: Spending on Wages and Salaries Per Employee: Local School Boards (2010)

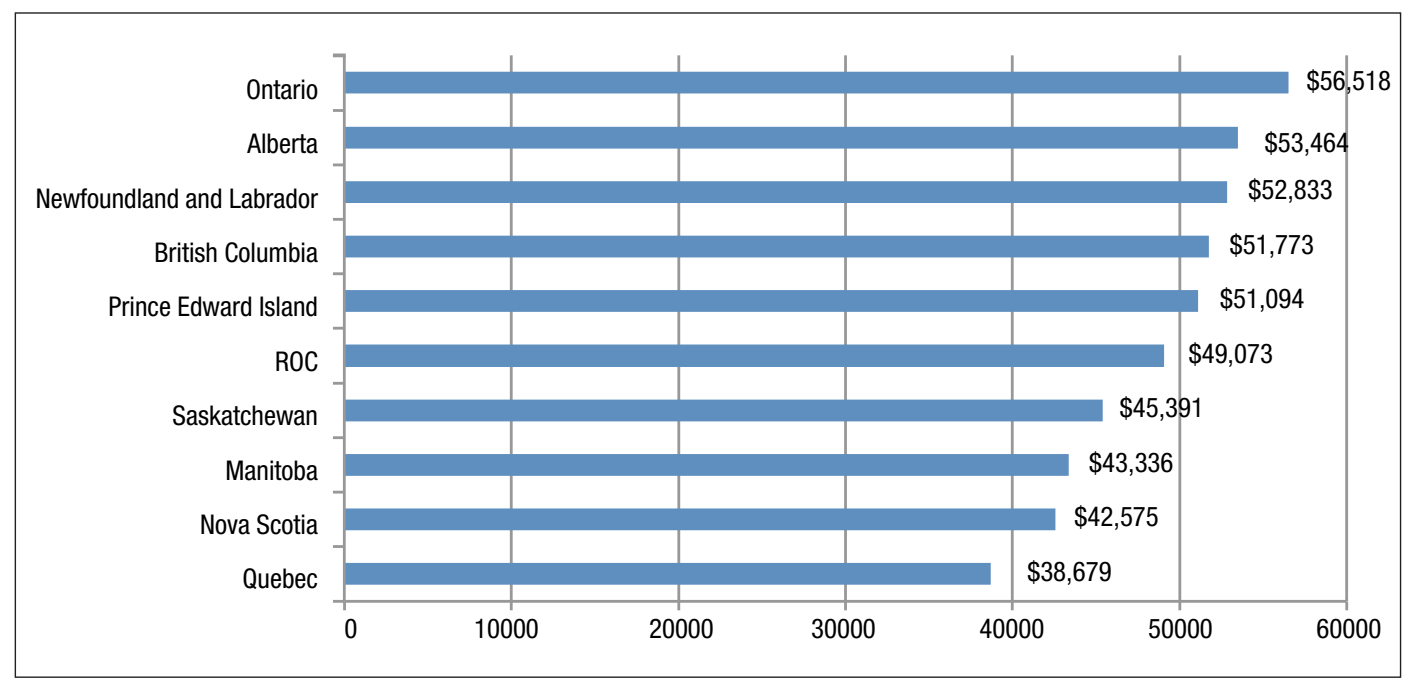




\section{Universities and Colleges}

For the higher education sector, in the year 2000, per-employee spending on wages and salaries in Alberta was already 15 percent higher than in the rest of Canada (Chart 2). Since that time, wage growth for employees at universities, colleges and vocational schools in Alberta has outstripped wage growth for workers in those institutions across the rest of the country. Peremployee wage and salary spending increased by 46 percent in Alberta compared to a 31 percent increase in the rest of Canada between 2000 and 2010. By 2010, per-employee spending on wages and salaries for this category was 28 percent higher in Alberta than in the rest of Canada (Chart 6).

In 2010, Alberta had, by far, the highest level of per-employee spending on wages and salaries for employees in this component of the public sector. Per-employee spending on wages and salaries stood at $\$ 64,528$ per employee in Alberta in 2010, while British Columbia, the next highest province, stood at $\$ 54,522$.

CHART 6: Spending on Wages and Salaries Per Employee: Universities and Colleges (2010)

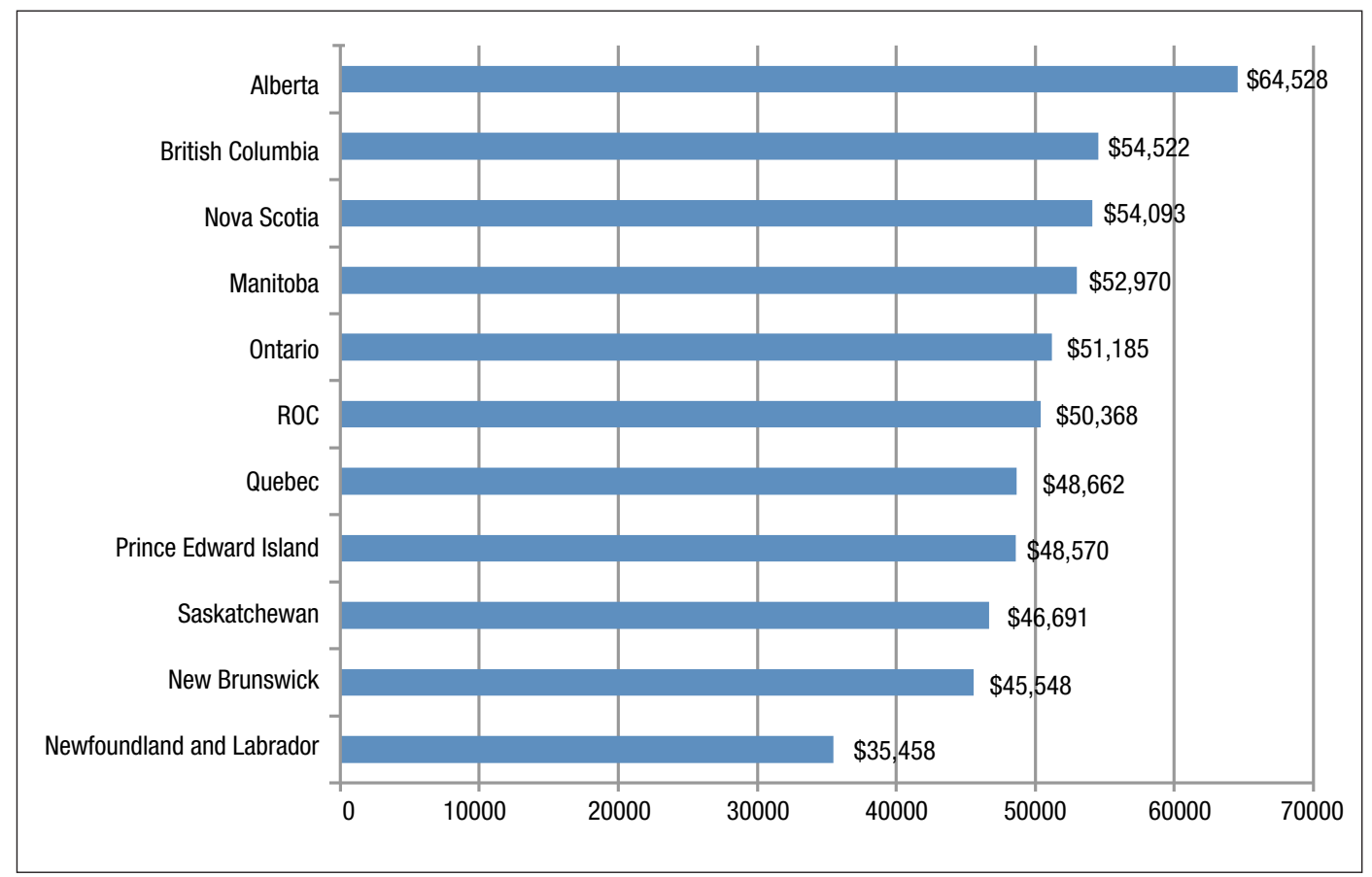

The previous six charts have shown that in the year 2000, per-employee spending on wages and salaries in Alberta was either slightly above or slightly below the national average for all five categories of sub-national public sector employees. For all five categories, wage growth in Alberta has outstripped wage growth in the rest of Canada over the past decade and, as a result, per-employee spending on wages and salaries in Alberta is now either the highest or the nextto-highest out of the 10 provinces in each of the five categories. 


\section{RESPONSES TO ANTICIPATED OBJECTIONS:}

\section{Rising Per-Employee Compensation Costs May Reflect Reductions in the Number of Public Servants and Rising Public Sector Productivity}

We have shown that government spending on wages and salaries per public sector employee has increased substantially at the sub-national level in Alberta over the past decade. However, this increase in per-employee compensation costs may conceivably be justifiable if public sector productivity in Alberta has increased substantially faster than in other provinces. For example, if the number of public sector employees has been shrinking, held constant or been growing at a slower rate than the population (assuming consistent quality of public services over time), the level of value provided to the government by each worker may be growing considerably over time, justifying higher levels of compensation per employee.

Statistics Canada data on the number of public sector employees does not support the notion that rising labour productivity is responsible for the remarkable increase in per-employee compensation in Alberta. Laurin and Robson note that even if no labour productivity improvements occur in government, "one might expect maintaining constant quality in the services delivered per Canadian to produce growth in the numbers of public servants in line with the growth in population." In other words, if labour productivity is constant over time, it is reasonable to expect the percentage increase in the number of government workers to roughly mirror population growth in a given jurisdiction.

However, in Alberta, the data show the number of sub-national government employees has increased considerably faster than population in recent years. Between 2000 and 2010, Alberta's population grew by 24 percent. During the same period, the number of sub-national public sector employees in Alberta grew by 40 percent. The ratio of government employees to population has grown considerably over the past decade. This data does not support the notion that the escalating per-employee compensation costs are the result of a changing public sector labour model in which there are fewer, but more productive employees which may justify quickly rising per-employee compensation costs.

\section{Alberta's Public Sector Workforce Is More Educated, Skilled and Experienced than in Other Provinces}

The composition of the public sector workforces in different jurisdictions in terms of the education, skills and experience of government employees may result in public servants being more productive in some provinces than others, justifying higher wages. If Alberta's public sector workforce members are markedly more skilled than public employees elsewhere, this may help justify the unusually high per-employee compensation costs in Alberta.

Unfortunately, it is notoriously difficult to measure differences in public sector composition. Furthermore, relevant comparative data on the skills, education and experience of employees in different public sector professions, which might shed light on likely productivity levels, is not readily available. However, the patterns in per-employee compensation in Alberta compared to Canada over the past 20 years suggest that this explanation is not particularly compelling.

In 1990, sub-national per-employee compensation costs in Alberta were roughly aligned with the Canadian average. As we have shown, the same was true in the year 2000. It is only over

4 Laurin, and Robson, 2011. 
the past decade that a gap has opened and quickly widened between per-employee compensation costs in Alberta and in the rest of the country. This suggests any differences in the composition of the public sector workforce in Alberta compared to the rest of the country in terms of skills, education and experience that might explain the current wage gap must have been the result of changes in the relative quality of the public sector workforce that have occurred over a short period of time. Further, a very large proportion of the public sector workforce in Alberta and Canada in 2010 is composed of the same people as were employed in the year 2000, although with 10 more years of experience. It is difficult to imagine that a gap in the skills, experience and education between new hires in Alberta and elsewhere in the country over the past decade could be so great as to explain significant divergence in the trajectories of per-employee compensation costs for the entire public sector workforce, including long-time employees. It is also conceivable that long-time public sector employees in Alberta have upgraded their human capital more extensively than public servants elsewhere over the past decade. However, the size of such a difference would have to be extremely large to explain per-employee compensation costs in Alberta that are now 20 percent higher than the national average in several areas.

Considering that per-employee compensation costs in Alberta were roughly aligned with the Canadian average just 10 years ago, it is difficult to imagine that changes in the composition of the public sector workforce in terms of the skills and experience of public employees over such a short period of time are sufficient to explain a large portion of the divergent trajectories in per-employee compensation costs we have documented in this paper.

A detailed comparative analysis of productivity levels for public sector workers across the country is beyond the scope of this paper. However, we note that there are no obvious meaningful differences in the educational and skills requirements for many of the most important types of public sector workers (teachers, nurses, etc.) between Alberta and peer jurisdictions. We submit it is incumbent upon defenders of the large Alberta public sector pay advantage to demonstrate the existence of a meaningful productivity gap resulting from different compositions of the public sector workforces.

We further submit that to demonstrate the benefits of the pay gap, it would be insufficient to show higher levels of credentials and experience among public sector workers in Alberta; it would also be necessary to demonstrate the beneficial impact of these credentials on the quality of public services. For example, have high levels of compensation in Alberta's health-care institutions led to consistently lower surgical wait times, markedly better patient outcomes or higher rates of access to family doctors in Alberta than in peer jurisdictions? At least two recent inter-provincial comparisons of health-care system performance suggest not. ${ }^{5,6}$

If there are defenders of Alberta's government wage advantage on the grounds of superior public sector human capital in the province relative to the rest of the country, the burden of proof rests with them to demonstrate the existence of a public sector human capital advantage and to show how this translates into better public services for residents.

5 Eisen, Ben, December 2011. Canada Health Consumer Index 2011 Winnipeg: Frontier Centre for Public Policy.

6 Ducket, Stephen, 2010. Alberta's Health Spending Challenge, Edmonton, Institute for Public Economics, Presentation to conference on 7 May 2010, Boom and Bust Again: Policy Challenges for a Commodity-Based Economy, found at http://www.ipe.ualberta.ca/en/EventsandSeminars/ media/ipe/ConferencesAndLectures/BoomAndBust/HealthcareExpenditures-IPE-70510.pdf on January 4, 2012. 


\section{Alberta's Public Sector Wages Must Compete With High Private Sector Wages To Attract Human Capital}

Over the past decade, private sector wages in Alberta have increased faster than in the rest of the country. This may mean that Alberta's public sector is subject to fiercer competition for talent from the private sector than most other provinces, which may place upward pressure on wages.

This argument is likely highly relevant for certain positions, such as employment in the Department of Energy or for senior management in the public services. However, many jobs in the public sector are specialized professions for which the government is the dominant employer. Teachers and nurses are obvious examples. For most professions in the health and education sectors, which comprise a very large part of the public sector, the Alberta government does not generally compete with the private sector for employees, but rather with other provinces. Although higher inflation and costs of living in Alberta may mean that a wage premium of some sort is necessary to compete effectively with other provinces for these employees, this is insufficient to explain the large wage gaps documented in this paper (particularly compared to other high-cost jurisdictions like British Columbia and Ontario).

Furthermore, Statistics Canada data suggests wage growth for several categories of public sector workers in Alberta has significantly outstripped private sector wage growth over the last decade. For example, Statistics Canada CANSIM Table 281-0027 shows that the average wage across the entire Alberta economy has increased by approximately 50 percent over the past decade. By comparison, the average wage for government employees classified as provincial public administration workers (a category roughly the same as the provincial general government category analyzed above) increased by 77 percent during the same period.

Eisen showed that provincial public administration wage growth across Canada was considerably faster than the economy-wide average over the past decade and these data show Alberta participated in this trend. ${ }^{7}$ In fact, provincial public administration wage growth in Alberta was the second fastest of all the major categories tracked by Statistics Canada over the past decade, exceeded only by "Management of Corporations and Enterprises."

\section{CONCLUSION}

Public sector wages in Alberta have shot up since 2000. Overall, the public sector wage bill in Alberta has increased 119 percent in the decade following the turn of the century, compared to 63 percent in the rest of Canada. On a per-employee basis, public sector wages in Alberta were broadly in line with public sector wages in the rest of the country in 2000, but are now higher, and in some cases significantly higher, across all categories.

In 2010 Alberta's general government per-employee wages were 35 percent higher than in the rest of Canada; its health and social services wages were 60 percent higher; its local school board wages were 10 percent higher; and its higher education wages were 30 percent higher.

7 Eisen, Ben, January 2011. Public Administration Wage Growth: Comparing Wage Growth in Industries Across the Canadian Economy Winnipeg: Frontier Centre for Public Policy. 
These numbers suggest that if the Alberta government is looking for ways of reducing spending to eliminate its deficit (or if they are looking to understand why Alberta is spending significantly more per person on government services than other provinces), they could do much worse than setting an objective of bringing their wages in line with those in other Canadian provinces.

While this paper does not conclusively demonstrate that public sector wages in Alberta are too high, the data presented here - and the sheer size of the per-employee wage gaps - certainly place the burden of proof on those who claim that Alberta public sector wages are reasonable. 


\section{BIBLIOGRAPHY}

Boessenkool, Ken. Does Alberta Have a Spending Problem? (Calgary, School of Public Policy, February 2010).

Ducket, Stephen, Alberta's Health Spending Challenge (Edmonton, Institute for Public Economics, Presentation to conference on 7 May 2010, Boom and Bust Again: Policy Challenges for a CommodityBased Economy, found at http://www.ipe.ualberta.ca/en/EventsandSeminars/ /media/ipe/ConferencesAndLectures/BoomAndBust/ Healthcare-Expenditures-IPE-70510.pdf on January 4, 2011)

Eisen, Ben. Public Administration Wage Growth: Comparing Wage Growth in Industries Across the Canadian Economy (Winnipeg: Frontier Centre for Public Policy, January 2011)

Eisen, Ben. Canada Health Consumer Index 2011 (Winnipeg: Frontier Centre for Public Policy, December 2011)

Laurin, Alexandre and William B.P. Robson. A Faster Track to Fiscal Balance: The 2011 Shadow Budget (Toronto: CD Howe Institute, February 2011).

Missouri Economic Research and Information Centre, NAICS Sectors (http://www.missourieconomy.org/about_us/naics_sect.stm accessed on September 10, 2010).

Mueller, Richard M. "Public- and Private-Sector Wages Revisited," Industrial Relations, 29(3), 275-400. Statistics Canada, Cansim, Various data series as noted in the text. 


\section{ABOUT THIS PUBLICATION}

The School of Public Policy Research Papers provide in-depth, evidence-based assessments and recommendations on a range of public policy issues. Research Papers are put through a stringent peer review process prior to being made available to academics, policy makers, the media and the public at large. Views expressed in The School of Public Policy Research Papers are the opinions of the author(s) and do not necessarily represent the view of The School of Public Policy.

\section{OUR MANDATE}

The University of Calgary is home to scholars in 16 faculties (offering more than 80 academic programs) and 36 Research Institutes and Centres including The School of Public Policy. Under the direction of Jack Mintz, Palmer Chair in Public Policy, and supported by more than 100 academics and researchers, the work of The School of Public Policy and its students contributes to a more meaningful and informed public debate on fiscal, social, energy, environmental and international issues to improve Canada's and Alberta's economic and social performance.

The School of Public Policy achieves its objectives through fostering ongoing partnerships with federal, provincial, state and municipal governments, industry associations, NGOs, and leading academic institutions internationally. Foreign Investment Advisory Committee of the World Bank, International Monetary Fund, Finance Canada, Department of Foreign Affairs and International Trade Canada, and Government of Alberta, are just some of the partners already engaged with the School's activities.

For those in government, The School of Public Policy helps to build capacity and assists in the training of public servants through degree and non-degree programs that are critical for an effective public service in Canada. For those outside of the public sector, its programs enhance the effectiveness of public policy, providing a better understanding of the objectives and limitations faced by governments in the application of legislation.

\section{DISTRIBUTION}

Our publications are available online at www.policyschool.ca.

\section{DISCLAIMER}

The opinions expressed in these publications are the authors' alone and therefore do not necessarily reflect the opinions of the supporters, staff, or boards of The School of Public Policy.

\section{COPYRIGHT}

Copyright (C) 2012 by The School of Public Policy.

All rights reserved. No part of this publication may be reproduced in any manner whatsoever without written permission except in the case of brief passages quoted in critical articles and reviews.

\section{ISSN}

1919-112x SPP Research Papers (Print)

1919-1138 SPP Research Papers (Online)

\section{DATE OF ISSUE}

January 2012

\section{MEDIA INQUIRIES AND INFORMATION}

For media inquiries, please contact Morten Paulsen at 403-453-0062.

Our web site, www.policyschool.ca, contains more information about The School's events, publications, and staff.

\section{DEVELOPMENT}

For information about contributing to The School of Public Policy, please contact Candice Naylen by telephone at 403-210-7099 or by e-mail at cnaylen@ucalgary.ca.

\section{EDITOR}

Timothy Giannuzzi 


\section{RECENT PUBLICATIONS BY THE SCHOOL OF PUBLIC POLICY}

CATCHING THE BRASS RING: OIL MARKET DIVERSIFICATION POTENTIAL FOR CANADA http:// policyschool.ucalgary.ca/ sites/default/files/research/mmoore-oilmarket.pdf M.C. Moore, S. Flaim, D. Hackett, S. Grissom, D. Crisan and A. Honarvar | December 2011

THE CONSTITUTIONALITY OF FEDERAL CLIMATE CHANGE LEGISLATION

http:/ / policyschool.ucalgary.ca/?q=content/ constitutionality-federal-climate-change-legislation Alastair Lucas and Jenette Yearsley | December 2011

THE MYTHS AND FACTS OF FOSSIL FUEL SUBSIDIES: A CRITIQUE OF EXISTING STUDIES http:/ / policyschool.ucalgary.ca/files/ publicpolicy/MCKENZIE\%20MINTZ\%20online.pdf Kenneth J. McKenzie and Jack M. Mintz | October 2011

HOMELESSNESS IN ALBERTA: THE DEMAND FOR SPACES IN ALBERTA'S HOMELESS SHELTERS http:// policyschool.ucalgary.ca/files/publicpolicy/homelessness\%20in\%20alberta.pdf Ronald Kneebone, J.C. Herbert Emery and Oksana Grynishak | September 2011

THE NEW SECURITY PERIMETER WITH THE UNITED STATES

http:// policyschool.ucalgary.ca/files/ publicpolicy/flemming\%20sept011.pdf Brian Flemming | September 2011

INCOME SUPPORT FOR PERSONS WITH DISABILITIES

http:// policyschool.ucalgary.ca/files/publicpolicy/Kneebone_Disability_Study.pdf

Ronald Kneebone and Oksana Grynishak | September 2011

INVESTMENT REVIEW IN CANADA - WE CAN DO BETTER

http:// policyschool.ucalgary.ca/files/publicpolicy/Herman\%20Invest\%20Canada\%20online.pdf Lawrence L. Herman | September 2011

PLUCKING THE GOLDEN GOOSE: HIGHER ROYALTY RATES ON THE OIL SANDS GENERATE SIGNIFICANT INCREASES IN GOVERNMENT REVENUE

http:/ / policyschool.ucalgary.ca/files/public policy/KMckenzie\%20comm\%20sept11.pdf

Kenneth J. McKenzie | September 2011

ENVIRONMENTAL BENEFITS OF USING WIND GENERATION TO POWER PLUG-IN HYBRID ELECTRIC VEHICLES http:/ / policyschool.ucalgary.ca/files/ publicpolicy/enviro\%20hybrid\%20wind\%20energy.pdf

Mahdi Hajian, Monishaa Manickavasagam, William D. Rosehart and Hamidreza Zareipour | August 2011

A FRESH START ON IMPROVING ECONOMIC COMPETITIVENESS AND PERIMETER SECURITY

http:/ / policyschool.ucalgary.ca/files/ publicpolicy/dburney.pdf

Derek H. Burney | August 2011

PIIGS “Я” US?

http:/ / policyschool.ucalgary.ca/files/ publicpolicy/US\%20debt\%20crisis.pdf

Stephen R. Richardson | July 2011

RHETORIC AND REALITIES: WHAT INDEPENDENCE OF THE BAR REQUIRES OF LAWYER REGULATION http:// policyschool.ucalgary.ca/files/publicpolicy/A_Woolley_lawregulat_c.pdf

Alice Woolley | June 2011

TAX IMPACT OF BC'S HST DEBATE ON INVESTMENT AND COMPETITIVENESS

http:/ / policyschool.ucalgary.ca/files/ public policy/tax\%20impact\%20BCHST\%20communique\%20c.pdf Jack Mintz | May 2011 